\title{
Gender and Human Rights Implications of Women Trafficking in Northern Nigeria
}

\author{
Maryam M. Jungudo
}

Department of History and Diplomatic Studies, Federal University, Kashere, Gombe State, Nigeria

\author{
Doi:10.5901/mjss.2014.v5n26p15
}

\section{Abstract}

One major crime in today's contemporary international law is human trafficking. It is essentially a gender-based phenomenon because many of the victims are women and girls. While it may appear that the problem seems to be more in the southern axis of Nigeria, there is indication that the Northern axis of Nigeria is not immune from this social malaise that has ravaged many countries in the world. In the northern Nigeria, the traffickers also known as 'Hajiya' recruit their victims mostly through delusion in their desire to go to Saudi Arabia for pilgrimage but whom unfortunately, were later forced into street begging, domestic labour and even prostitution. However, the implications of this phenomenon are many which include the infringement upon women's right and dignity in which increase in exposure to sexually transmitted disease, psychological and physical abuses, despite the fact that Nigeria is a signatory to many International and national Instruments, in terms of protecting the human rights and dignity of its citizens. This paper examines the implications of women trafficking in Northern Nigeria as it impinges on their human right. While it looks at the official efforts at counter-trafficking, it further analyses the challenges being encountered in the process on the basis of which recommendations are to be made.

Keywords: Gender, Women, Human Trafficking, Human Right, Northern Nigeria

\section{Introduction}

The History of the world has recorded the ugly story of both the Trans-Saharan and Trans-Atlantic slave trades that adopted trafficking in its strategy. Ironically, while the world was shouting hurray to the end of slavery, the contemporary world has witnessed its emergence in the form of human trafficking. Trafficking in human beings in general and women in particular has become a general phenomenon. It is a complex, multi-faceted phenomenon involving multiple stakeholders at the institutional and commercial level. In Africa, Nigeria (the Giant of Africa) has acquired a reputation for being one of the leading countries in human trafficking with cross-border and internal trafficking. After economic fraud and drug trade, trafficking of women and children is the third largest crime in the country (UNHCR: 2000). In 2007, marking the 200 years anniversary for the abolition of slave trade, the United Nation Researchers and other expert agreed that approximately 800,000 persons are trafficked across the world countries border each year. Therefore, the scourge of human has over the years increased considerably because of poverty, large family size, lack of educational opportunities and lack of employment, ignorance on the part of families, porous borders, corrupt government officials, involvement of international organized crime groups or networks, limited capacity of or commitment by immigration and law enforcement officers to control trafficking at the borders and lack of political will or desire to enforce existing legislation or mandates.(UNODC 2006:10)

In addition, Nigeria is a country of origin, transit and destination for human trafficking (Mashi, 2005: 3). Destinations for trafficked Nigerians include the neighbouring West African countries, (Côte d'Ivoire, Mali, Benin, Equatorial Guinea, Cameroon, Gabon and Guinea), European countries, (Italy, Belgium, Spain, the Netherlands, Germany and the United Kingdom), North Africa (Libya, Algeria and Morocco) and Middle Eastern countries (Saudi Arabia and United Arab Emirates). Recently, South America has also become a point of destination for trafficked persons, particularly Venezuela.

It is worthy to note that, despite Nigeria is a signatory to many International and national legal Instruments in terms of protecting the human rights and dignity of its citizens, especially women, such as the United Nations Convention on the Declaration of Human Rights (1948); the United Nations Convention o Elimination of All Forms of Discrimination Against Women (1979); the United Nations Convention on the Rights of the Child (1989); the Trafficking in persons (Prohibition) Law Enforcement and Administration (2003), Palermo Protocol and Convention on the Elimination of all forms of Discrimination Against Women (CEDAW), victims of this phenomenon suffers

This paper, therefore, discusses the human right implications on gender and women trafficking in Northern Nigerian axis. Based on findings from quantitative studies, the research argues that despite several factors that have been adduced for the degrading position of women in the Nigerian society, it could also be right to trace this phenomenon 
to the gender insensitivity of not only the male folk but the entire society including the women who have been socialized to accept the inferior status.

\title{
2. Conceptual Clarifications
}

Gender is the socially and culturally constructed roles for men and women. For instance, gender roles of men as owners of property, decision makers and heads of household are socially, historically and culturally constructed and have nothing to do with biological differences. It is important to note the difference between sex and gender. Sex refers to the biological differences between male and female. For instance, the adult female has breast that can secrete milk to feed a baby but the adult male does not have. Gender roles differ from place to place and change with time. But sex roles are naturally fixed (Makama 2003:118).

Famuyiwa (2007:13) describes gender as a term which imposes division between sexes socially and corrects the emotional and psychological attitude which a given culture expects to coincide with physical maleness or femaleness. However it is a cultural construct that distinguishes the role between females and males developed by the society. It could be right to say that gender is always used to mean men and women.

Gender relations are part of social relations, referring to the ways in which the social categories of men and women, male and female, relate over the whole range of social organization, not just to interactions between individual men and women in the sphere of personal relationships, or in terms of biological reproduction but in all aspects of social activity, including access to resources for production, rewards or remuneration for work, distribution of consumption, income or goods, exercise of authority and power, and participation in cultural, political and religious activity. Gender relations describe the social meaning of being male and female, and thus what is considered appropriate behavior or activity for men and women (Pearson: 2000:18).

The first internationally agreed upon definition of trafficking is embodied in the Article 3 of UN Protocol (Palermo Protocol) to Prevent, Suppress, and Punish Trafficking in Persons, Especially Women and Children, Supplementing the UN Convention Against Transnational Organized Crime (2000), as follows:

The recruitment, transportation, transfer, harboring or receipt of persons, by means of the threat or use of force or other forms of coercion, of abduction, of fraud, of deception, of the abuse of power or of a position of vulnerability or of the giving or receiving of payments or benefits to achieve the consent of a person having control over another person, for the purpose of exploitation. Exploitation shall include, at a minimum, the exploitation of the prostitution of others or other forms of sexual exploitation, forced labor or services, slavery or practices similar to slavery, servitude or the removal of organs. The consent of a victim of trafficking in persons to the intended exploitation... shall be irrelevant where any of the... [fore-mentioned] means... have been used. The recruitment, transfer, harboring or receipt of a child for the purpose of exploitation shall be considered' trafficking in persons,' even if it does not involve ... [any of the above listed means]. "Child" shall mean any person less than eighteen years of age. (UNESCO 2006:19)

Trafficking in Persons (Prohibition) Law Enforcement and Administration (2003) defines Trafficking as:

\begin{abstract}
"All acts involved in the recruitment, transportation within or across Nigerian borders, purchases, sale, transfer, receipt or harboring of a person, involving the use of deception, coercion or debt bondage for the purpose of placing or holding the person whether for or not in involuntary servitude (domestic, sexual or reproductive) in forced or bonded labor or in slavery-like conditions." (Shantsari: 2012:121)
\end{abstract}

The above mention definition, although similar to the internationally accepted definition, is slightly and not insignificantly different from it in phraseology.

\section{Women Trafficking in Northern Nigeria}

Women trafficking in the northern Nigerian axis have a relatively long history. It was believed that it has started as early as in the 1980's, when cripples and disabled persons were trafficked by air from Malam Aminu Kano International Airport, Kano to Makka not only to perform pilgrimage but to be exploited as beggars. Accordingly, Lipede (2007) reported that there was improved immigration records that helped debunk the erroneous impression that human trafficking for prostitution does not occur in the northern axis. She reported that: "From March 2002-April 2004, the Saudi Arabia authorities deported 9,952 women and 1,231 underage unaccompanied children. Investigations revealed that the majority of the women deported from Saudi Arabia are from: Kano, Borno, Adamawa, Yobe, Nassarawa, Plateau, Niger, Kebbi, Kwara, Sokoto, Katsina, Zamfara, Jigawa, Gombe, Bauchi and Taraba States." Between 1999 and July 2000, traffickers 
deported about 454 trafficked Nigerians, mostly women and children, from Saudi Arabia. There is no doubt that the periods of the pilgrimage-Haij- or lesser pilgrimage- Umrah- exercises are used to trafficked women to Saudi Arabia not to engage in hajj but rather prostitution, begging, labour, among other illegal act (Lipede: 2005:12)

Local intermediaries or agents manipulate the religion of Islam to ensure that trafficked person's honour agreements and pay their debts. Traffickers in the northern axis include the arrangers in the supply states, the 'trolleys', who are the agents both in consumer states and in the destinations called madams, also called "Maman", they are female traffickers who meet all travel expenses (including the purchase of illegal documents when necessary) and all necessary costs in the first phases of the settlement abroad. They give their psychological support to the selected woman throughout the process of decision to expatriate, they advise her on how to behave in the foreign country, they provide her with useful addresses, such as that of the future working place, that of other 'Maman' ready to receive and help her solving possible problems either at the airport or during the course of her stay. (UNODC 2006:57). Kano for instance are believed to be vulnerable and exit state, while Katsina, Jigawa, Zamfara, Kebbi, Sokoto, Gombe, Yobe, Bauchi, Taraba, in the north are the consumer states. Transportation by air is increasingly difficult due to heightened security controls. Nonetheless, traffickers still manage to get through without being caught. But those going to Saudi Arabia justify their travel under the guise of Islamic pilgrimage.

\subsection{Purpose of Women Trafficking in Northern Nigeria}

Sexual exploitation: Young girls from nearly all the northern states are potentially vulnerable, contrary to the common belief that trafficking for commercial sexual exploitation is limited to the southern part of Nigeria. In the North, religion is used as a means to lure the innocent just as it is in the South, where the majority of trafficked persons are Christians. However, Prostitution in Nigeria is perceived as an aberrant and immoral act and is considered a sin, especially according to the religious teachings of Islam and Christianity prevalent in the country. In the northern part of Nigeria, the penal code is fashioned along Islamic laws and criminalizes prostitution. However, the sexual exploitation of women constitute a grave abuse of fundamental right which was vividly stated in Article of the Convention on the Elimination of all Forms of Discrimination Against Women (CEDAW). In it, CEDAW enjoins state parties to take all appropriate measures to suppress all forms traffic in women and exploitation of prostitution of women (Ojiakor: 2010:313)

Begging: the physically challenged or disabled persons, such as the blind and crippled that are lured into the begging business in Northern Nigerian cities, have recently spread beyond the country's borders to the Middle East, in particular to Saudi Arabia. Contractual beggars are often adult's women, who are hired on a daily basis for begging. There are rampant abuses involved with this kind of arrangement a kind of 'use' and 'dump' attitude. In this, the 'investor' only releases the trafficked person when he has made sufficient profit. The physically challenged are often carried on their back, in a wheel burrow or wheel chair and taken around the town, the holy Mosque (Masjid-al Haram) from sunrise to sunset, often under harsh weather and dangerous traffic conditions. (Personal experience of the researcher during Hajj Pilgrimage in 2011).

A form of women trafficking currently under investigation also takes place in the Middle East by the Northerners involves the luring of young women to Saudi Arabia to be killed for blood money known as "diya". The method is quite simple: the trafficker, often women, takes a child trafficked to Saudi Arabia to go shopping; when she spots an affluent Arab's car, she pushes the victim in the path of the car to get run over and possibly killed. There are two types of penalties for anyone who kills another human being in Saudi Arabia. The first is the death penalty; the second is the offering compensation to the relatives of the dead victim, if the relatives accept ("diya"). The trafficker opts for the second option and obtains an equivalent of about Naira 3,500,000 (local currency, equivalent to some US $\$ 27,000$ ). The trafficker returns to Nigeria and informs the parents of the trafficked victim that she died of natural causes. The trafficker pays the parents about Naira 100,000 an equivalent (about US \$775) as the wages of the victim while in Saudi Arabia. Parents do not typically probe the trafficker's story, often accepting the death of the victim as the will of Allah. Many simply accept the supposed wages. There is little research on this form of trafficking, but our source suggest that those recruited are women and children from poor family backgrounds and rural communities (UNESCO 2006: 30)

\section{Legal Instruments for Women Trafficking in Nigeria}

Women's trafficking is a crime against all known laws. It contravenes both natural and sacred laws. Because of the crossborder nature of the crime of trafficking, and in order to suppress these practices and bring perpetrators to justice, the response at national and international levels have put in place a number of laws, treaties, conventions and protocols dealing with human trafficking. It is true that some of these legal instruments may not specifically address or mention 
trafficking, however, it is useful to observe that certain elements of these legal instruments revealed that trafficking has always been seen as not different from slavery, being primarily for sexual exploitation or force labor (Enaikele and Olutayo:2011:419).

At the international level, there are a number of treaties, laws, protocols and conventions that Nigeria is signatory to. Prominent among these are the United Nations Convention on the Declaration of Human Rights (1948); the United Nations Convention o Elimination of All Forms of Discrimination Against Women (1979); the United Nations Convention on the Rights of the Child (1989); the International Labour Organization (ILO) Convention on Forced Labour and Minimum Wage (1999); the United Nations Optional Protocol to the Convention on the Rights of the Child, especially on the Sales of a Child, Child Prostitution and Child Pornography (2002); and the United Nations Convention Against Transnational Organized Crime (2000). Others include the African Charter on Human Rights (1980); the Protocol on the Rights of Women in Africa (1981); Africa Charter on the Rights and Welfare of the Child (1990), and the Economic Community of West Africa States (ECOWAS).

At the national level, the National Human Rights Commission was established by the National Human Rights Commission Act, 1995, in line with the United Nations General Assembly Resolution No. 48/134 of 20 ${ }^{\text {th }}$ December 1993, which enjoins all member states to establish National Human Rights Institutions relative to their environment (www.nationalhumanright.org). In addition, the 1999 constitution provides for the respect and dignity of human persons. It provides in section 34(1) that no person shall be subjected to torture, in human or degrading treatment or held in slavery or required to perform compulsory labor. The rights of the citizens to the dignity of the human person against slavery, servitude, forced labor, prostitution and other forms of sexual exploitation is also enshrined in the criminal Code of the Southern Nigeria (Cap 42, 1990) and the Penal Code of the Northern Nigeria (Cap 89, 1963); Labor Act (Cap 198, 1990); and the Trafficking in Persons Law Enforcement and Administration Act (2003). The anti-human trafficking act is the most recent and crucial because it specifically addresses human trafficking. This anti-human trafficking law was a laudable move that culminated in the establishment of the National Agency for Prohibition of Trafficking in Persons (NAPTIP). There are several provisions (Sections 11 to 29, 32 and 46) of the antihuman trafficking act of NAPTIP prescribing different punishment ranging from one year to life imprisonment for serious offences such as exportation or importation of girls under the age of 18 years for prostitution, forced labor, servitude or removal of organ by means of threat or use of force or other forms of coercion, abduction, fraud or deception. The seriousness of this law is underscored by its section 61(1) which provides for: where an offence under the act is committed by any citizen or person granted permanent residence in Nigeria, she may be prosecuted in respect of such offence as if it was committed in any place within Nigeria. This law also vests the power to arrest, search and seize on police, immigration, custom and National Agency for Prohibition of Trafficking in Persons (NAPTIP) officials. (UNODC 68-71)

Similarly, the Federal and State High Courts have concurrent jurisdiction to try any of the offences under the law. For instance, the case between the Honorable Attorney-General of the Federation (the complainant) and Hussaina Ibrahim and Idris Adamu (alias VIP) (Accused persons), a decision of the High Court of Justice Kano delivered on 26 July, 2005 by Justice A. M. Haliru (Shantsari: 2012:118). This case depicts a concrete and successful prosecutorial action taken in Kano to punish women traffickers from Nigeria to Saudi Arabia for prostitution.

However, as the current incessant ethno-religious conflicts and Boko Haram menace in the Northern Nigeria continued to be a major concern in the region and an impediment to its development and progress, there is no doubt that it had created negative effects on the implementation of policies that can move the region forward. Most importantly, the issue of human right, a good example was the scourge of women trafficking. This phenomenon has no doubt infringed on the women's right as right pointed out in both the national and international human right declarations.

\section{Gender and Women Trafficking in Northern Nigeria: Unfolding the Human Right Implications}

Women who eager for a better future, are susceptible to promises of jobs abroad as babysitters, housekeepers, waitresses, or models jobs that traffickers turn to the nightmares of forced prostitution without exit. (The 2008 trafficking in persons report, USA)

Several factors have been adduced for the degrading position of women in the Nigerian society most of which can be traced to the gender insensitivity of not only the male folk but the entire society including the women who have been socialized to accept the inferior status. It is intriguing to note that the subordination of women knows no boundaries or barriers and is not dependent on the social, educational or economic status of the Nigerian women. Consequently one finds that an uneducated and poor woman in the rural community suffers as much subordination as an educated and rich woman in the urban centre.

However, Gender inequality is experienced by the women and is manifested in almost all aspects of human 
Endeavour in Nigeria. Cultural and Religious beliefs tend to contribute largely to Nigerian women's gender discrimination and low status. Some of these beliefs have been practiced for so long that they are embedded in the societal perception almost as legal norms. Consequent upon which the Nigerian woman suffers violations of her rights from conception till she dies without redress by the society; At birth the male child is preferred to the female, as she grows the female child suffers various forms of violence such as genital mutilation, In the home she is denied education in preference to her male counterpart and subjected to heavy burden of household chores. As a woman she encountered marital, poverty, trafficking among others.

Although in International law, trafficking, has long been recognized as a form of human rights abuse, only recently has it been recognized by the international community as a violation of women's right. According to Section 42(1), Constitution of the Federal Republic of Nigeria, 1999; Article 2 of African Charter on Human and Peoples' Rights; Article 2. Convention on the Elimination of All Forms of Discrimination Against Women (CEDAW) among other national and international legal instruments, they supported the elimination of all forms of discrimination against women in the private and public sectors and improvement in levels of equality and enjoyment of women's human rights in policy formulation. They also encourage increased access by women and girls to education, reduction of disparities in women and girls literacy, enhanced access to health information and services amongst others. Despite the provisions, women and girls are still being discriminated against and treated as mere objects and chattels. Nigeria is yet to match its obligations with action through the domestication of the CEDAW, which is long overdue. Hundreds of thousands of women have been sold into slavery, as wives or prostitutes, after being kidnapped or tricked into going with traffickers. The Nigeria government has repeatedly committed itself to eliminating the trafficking of women, as the phenomenon continued to swell up over the last decade and has no doubt affected the lives of so many women under this inhuman lifestyle; be it health, security, emotionally, psychologically, socially, mentally, and so on. In addition, the phenomenon also has implications on human right and dignity of its victim, because it destroys the natural good in an individual, not be seen with dignity, self respect and self esteem; these victims of trafficking are also victims of sexual exploitation; Perhaps, some of them are found missing or do not find their way back home.

The story of women trafficking captures the picture of the life of an unfortunate individual, usually women, whom were caught in between the 'Rock and the Hard place' culminating in the infringement upon their human right and dignity. The case of Sakina Ibrahim is a good example to that effect.

In 2004, Sakina Muhammad was recruited and transported to Saudi Arabia by one of the 'Madame' in Kano by name Hussaina Ibrahim and her partner in crime Idris Aminu (Alias VIP). They arranged for her to have an international passport, worked to procure her a Visa, paid for her airfare, and provided her with a male escort and arranged an accommodation for her in Saudi Arabia. Unfortunately, the poor Sakina, was tricked into embarking on the journey by the so-called Madame, who told her that they were assisting her to 'solve her dire economic problems'. They also gave her the impression that she would have good fortune of marrying an Arab or a Nigerian or get a Boyfriend on her arrival in Saudi Arabia. As soon as she arrived, her passport was ceased. She was also introduced into prostitution and put under surveillance. Her routine was to have sex with 5 men as she was the most popular new arrival and was being paid SR 50, (N2000 or $\$ 13$ ) for quick sex and SR 300 (N12,000 or \$73) for overnight sex. All the payment for the prostitution were being collected by her handlers and it was out of such payment that her traffickers were making deductions as reimbursement for the expenses she incurred in transporting the victim to Saudi Arabia. Both Sakina and Hussaina,( her 'Madame') were later deported to Nigeria by the Saudi Arabian authority, while the National Agency for the Prohibition of Traffic in Persons and NAPTIP conducted an investigation and charged the two persons under the 2003 act.(Shantsari :2012:121-123)

The victims' of trafficking are mostly poor women, frequently recruited for exploitation. They are often subject to threats and violence by their traffickers. Arising from this are various health hazards that the victims are exposed to through unprotected sexual intercourse, which their client are more ready to pay for. The victims are forced to endure intercourse with multiple partners. Some of them experience psychological and Physical abuses. In addition, victims are more likely to experience fear, guilt, sense of betrayal, lack of trust, suspicious, sense of apathy, shame, resignation to fate, hopelessness, extreme form of submissiveness, and a sense of loss of personal autonomy such as initiative and integrity. This could easily result to taking drugs, as well as being much more likely to inflict self injury or even commit suicide. Victims of women trafficking are not always recognized as trafficked victims but are still often viewed as, at best illegal migrants, and at worst, as illegal migrant prostitutes. Their almost immediate deportation (referred to in kinder terms as repatriation) violates the rights that should be accorded to trafficked victims under the UN Protocol to Prevent, Suppress and Punish Trafficking in Persons, Especially Women and Children. A problem facing trafficked women mentioned in a number of studies is the fact that when they are arrested in the destination countries they are often locked in police cells and deported without having been given the opportunity to collect their belongings or money. 


\section{The Challenges of Counter-Trafficking in Northern Nigeria}

- Gender inequality is the principle driving force behind this trade, propelling vulnerable people into the hands of traffickers, who belong to both small-scale, local enterprises with extensive criminal networks and to large scale multi-commodity businesses.

- There are systemic problems which have been identified as particular challenges in fighting trafficking, and problems which require more long-term approaches. These are high levels of unemployment and poverty, denial by parents, government and communities of the existence or seriousness of the offence, the low status of women and female children, and the lack of free, quality education coupled with weak social welfare institutions.

- Human trafficking naturally involves the issue of border controls. Border controls within the ECOWAS region and some international airport are weak and border-crossing relatively easy; the whole area is replete with the unregulated circulation of people moving informally from one country to another.

- Another area is the impact of broken homes on the vulnerability of women to trafficking. Profiles of trafficked persons revealed that most of the trafficked women were products of broken homes.

- Numerous challenges exist in both the enforcement of anti-trafficking measures as well as the prevention of trafficking and the protection of victims.

- Much of the work in trafficking is hampered by the absence of adequate information on sponsors, traffickers, movement of victims, and other information from the general public as well as information from neighbouring countries. Victims and their care pose a particular challenge to all involved in working with them.

\section{Recommendations}

To better combat women trafficking in Nigeria and the attendant human rights implications in the Nigerian society, the following recommendations are made:

- The government: The government should stimulate the creation and maintenance of an inter-agency board or task force within Nigeria. There needs to be more coordination between agencies on the management of victims. Collaboration is recommended between local, state and the national government. International cooperation should be increased through bilateral and multilateral agreements and Memoranda of Understanding. Free education or scholarships should be provided to victims who want to return to school to complete their education (compulsory and free education for all children may decrease children's susceptibility to trafficking). Creation of more employment opportunities in Nigeria will provide more economic alternatives for children and adults. Strengthening border controls is a potential strategy, as less porous borders make the traffickers' job far more difficult. One should note, however, that tighter borders simultaneously increase demand for the illegal transport provided by traffickers among migrants and smugglers. Thus, any controls must be implemented carefully and intelligently. In addition, There is a continuing need for the further ratification and implementation of international legislation along with the use of national legal tools currently available to fight against trafficking in human beings. The persistence of harmful cultural practices, the growth of the reach and influence of organized crime and the persistent loss of young women and children to sexual and forced labour exploitation require concerted and constant aattention.

- Community: by involving the community in a partnership in the fight against trafficking by fostering the establishment of "youth vigilante groups" in all villages to identify traffickers and act as informants to the police. Another proposal was for more television and radio jingles on trafficking.

- Private Sector: Creation of employment opportunities and funding from the private sector would provide opportunities and means for those at risk to improve their lives at home rather than taking a risk abroad. This could help reduce trafficking.

- The Law: Procedures should be adopted that would remove bottlenecks and delays in prosecuting traffickers. Existing laws should be expanded to include victim/witness protection and provide for compensation payments to victims. Seizure of traffickers' property and financial assets and forfeiture to the government should be ensured.

- Victims and those at risk: Community enlightenment projects on the dangers of human trafficking are welcome development. This can be done through personal contact or through television and radio jingles on trafficking. Victims should first be kept in rehabilitation centre before returning them to their parents. An investigation 
should be made to determine if the child could be safely returned home. Shelters centre and rehabilitation projects including counselling for trafficked victims are a necessity. Furthermore, the status of the victim must be recognized and the (particularly adult) victims must not be treated like criminal illegal migrants (or prostitutes). The victims' family must be involved in the rehabilitation process. It is essential that the government establish a viable witness-protection programme that would guarantee protection for victims, witnesses and complainants. More so, 'Trafficking' hotlines need to be established for victims and victims need to be made aware of existing services and facilities. Grants and micro-credits to graduates of skills acquisition programmes will provide them the means to remain in Nigeria and support themselves and their families.

\section{References}

Enaikele M.D. and Olutayo A. O. (2011). Human Trafficking In Nigeria: Implication for Human Immune Deficiency Virus And Acquired Immune Deficiency Syndrome (HIVIAIDS) Pandemic in International Journal of Sociology And Anthropology Vol. 3(11), Pp. 416422.

Famuyiwa M.O. (MNHCl) (2007), Gender Issues in Reply to Vocational Education in Nigerian Environment. Nigerian Journal of Gender and Development, Vol 7 No1 March ad Vol 7 No1 September 2007. pp 13-24. 1ISSN 1595-7594

Lipede A. (2007). In Africa Strategic and Peace Research Group, Barkindo B. M. And Lipede A. (Eds) Human Trafficking and Economic Crimes Across Nigeria's International Borders. Spectrum.

Makama G. A. (2013). Patriarchy and Gender Inequality in Nigeria: The Way Forward, European Scientific Journal, June 2013 Edition Vol.9, No.17. pp 115-144. ISSN 1857 - 7881.

Mashi M.A. (2005). The State of Human Trafficking in Nigeria, A paper presented at a workshop organized by the Nigerian Immigration Service, Bauchi State, Nigeria.

Orjiakor N., Gender and Women Trafficking in Nigeria, in Abdullahi M. Ashafa (Ed) Challenges for Nigeria at 50: Essays in Honour of Professor Abdullahi Mahadi.Kaduna State University Press 2010. Pp 305-318. (ISBN: 987-2528-01-3)

Oyekanmi, F. D. (2005). "Gender Issues in Globalization: An Overview of the Situation in Africa", in Oyekanmi, F.D. (ed.) Development Crisis and Social Change, Department of Sociology, University of Lagos, Lagos, pp 146-173.

Pearson, R. (2000), "Rethinking Gender Matters in Development" in Allen, T. and Thomas, A. (Eds), Poverty and Development into the 21st Century. Oxford, Oxford University Press.

Shatsari R.S (2012). Conviction for the offence of trafficking for forced prostitution Abroad: a note case of Hussaina Ibrahim. A Journal of Sociological Studies, Vol. 1 No.2 Bayero University Kano, pp 118-125.

U.S. department of State.The trafficking in persons Report 2008. Office to Monitor and Combat trafficking in Persons, USA. 2008.

United Nation High Commission for Refugees (UNHCR) (2000) A Multi-Billion Dollar Trade in Human, in Refugee UNHCR, Geneva.

United Nation Office on Drugs and Crime (UNODC): Measures to Combat Trafficking in Human Beings in Benin, Nigeria and Togo, UNODC Report/Document, September 2006.

UNESCO (2006). Human Trafficking in Nigeria: Root, Causes and Recommendation, http://unesdo.unesco.org/images/0014/001478/14788e.pdf accessed on 28/April/2014 